\title{
The influence of Frayer model strategy towards students' vocabulary mastery at the eighth class of SMPN 26 Bandar Lampung in 2017/2018
}

\author{
Effrina Yuricki \\ Universitas Indraprasta PGRI \\ Correspondence: effrina@unindra.ac.id ${ }^{1}$
}

\begin{abstract}
Students' vocabulary mastery is influenced by many factors. One of them is the technique, which the teachers use in teaching. In this research, the writer applied Frayer Model Strategy to teach vocabulary in the classroom. Then the writer analyzed the result of the technique in order to know its influence. The research was conducted at the eighth class of SMPN 26 Bandar Lampung in 2017/2018. The students of G1 as the sample that was taught by using Frayer Model Strategy and G2 that was taught by using conventional technique. In this case, the writer used two classes as the sample, the first class as experimental class (29 students) and the second class as a control class (28 students) from 265 students of eight classes. The sample was gotten by random sampling technique and the research was the experiment method. In collecting the data, the writer used objective test that is multiplechoice test contains 40 questions. The technique of analysis data in this research is used product moment formulation. The result of the research shows that there is a significant influence of Frayer Model Strategy towards Students' Vocabulary Mastery at the eighth class of SMPN 26 Bandar Lampung in 2017/2018. They are less than t-test 7.16. Finally, the writer concluded that there is a significant influence of Frayer Model Strategy towards students' vocabulary mastery at the eighth class of SMPN 26 Bandar Lampung in 2017/2018.
\end{abstract}

Keywords: Frayer model strategy, vocabulary mastery 


\section{Introduction}

Language is a tool of communication, because without language, we cannot communicate with each other and it is a very important in social interaction in the world. Language is used to express ideas, feeling and experience with other people in social life. Each of people has culture and languages. Every culture has value. For introduces it, every people or country use one language. One of some languages are English. We can use English to communicate with the people all over the world.

In Indonesia, English is the first foreign language and the most important to be learned. We should master English first because most of the book or literature is written in English. Learning English as foreign language involves the mastery of structure, vocabulary, pronunciation and spelling as elements which support the four skills of English mastery and development namely: listening, speaking, reading and writing.

In learning English, vocabulary is the one of important roles because when the students express their idea they should have many vocabularies. Vocabulary is the basic element of language and with many vocabularies, we can know the meaning of the sentences and we can communicate with other people well. When we want to chat with someone we should know the words that will be used to convey our messages, we also should know the meaning of the word in order to keep the message would not be misunderstanding.

Based on preliminary research, the writer found that the students got difficult to increase their vocabulary. Some of them got difficult in mastering the words. Therefore, the writer assumes it happened because some factors, the teacher did not use the various methods or strategies in the English language teaching process and the students had limited time to study. To solve this problem the writer conducted alternative strategy in teaching vocabulary by implementing Frayer Model Strategy. Frayer, Frederick and H.J Klausmeier in Kinberg Margot (2007, p. 26) state that the Frayer Model is especially useful for teaching vocabulary that describes complex concepts or vocabulary that describes concepts students may already know but cannot yet clearly define.

Based on the identification above, the writer was interested to apply Frayer Model Strategy in teaching vocabulary. In this research, the writer tries to find out the influence of teaching vocabulary through Frayer Model. Therefore, the writer proposed a research entitles "The Influence of Frayer Model Strategy towards Students' Vocabulary Mastery at the Eighth Class of SMPN 26 Bandar Lampung in 2017/2018". 


\section{Literature review}

Language is very important. It can be used for communication one to another. By using language, we can express our ideas, feeling, and opinion. Besides that, it also can make someone knows and understands what others think or mean. It becomes a connector in their communication. People use language in any field of their daily activity in their social life. Language is a system of communication consists of sounds, words, and grammar or the system of communication used by the people of particular country of profession.

Language is a system for the expression of meaning; primary function, interaction and communication, conveys message and consists of sound and meaning. So it can be said that, "Language as discourse; applied linguistics into a study of language function and the appropriate use of language in different situation" (Harmer, 2001, p. 25). Based on the statement above, we can describe that by using language in our life can get new things, new information, feeling and meaning; to learn, to discover and to create the world of the imagination. In the other words, language is a key in communication. We can communicate with others in a form of language. Therefore, English is the one of the languages used by many countries in the world and English as a foreign language.

Language is a tool of communication. It is difficult to do all our activities without language, because people do interaction or convey their ideas and feeling that have been arranged according to listener needs.

From the description above it is clear that language is characteristics of country. Language is influenced cultural. Every country has different culture so they also have different language. When we communicate with other people, our dialect would be heard one and others. For example, Chinese, India, Malaysia, Indonesia have different culture and their languages are also different. Therefore, the writer said that language and culture has relation and their language become their characteristics of country.

\section{Teaching and learning English as a foreign language}

As we know that English is the first foreign language in Indonesia. It is taught from Elementary school up to University. It is expected that the students of Indonesia are able to use English both in written and spoken. Nowadays, it is easier for students to learn English. They not only can learn it in their school but also from English course, English book, English newspaper and magazine, film and internet.

Cameron (2001, p. 241) states, "The foreign language that children will learn has been mapped out by starting from vocabulary and discourse, as two aspects of language that offers most opportunity for seeking and finding meaning to children". The statement means, the people can produce language and interaction to other people support two aspects vocabularies and discourse. 
Furthermore, Harmer (2004, p. 39) states, "English is the foreign language is generally taken to apply the students who are studying general English at school and institute in their country or as transitory visitor in target language country". It means that in teaching English as foreign language creates a situation that the students can use English as a meant of communication. The students should be put into real situation that they could use English for communication both spoken and written.

Based on the opinion above, the writer concluded that communicative approach is very important to study about English as a foreign language with the communicative approach can help the students to study easily. The students get the language from their daily activity that they do. The students are motivated to use the language they are learning into a communication with others with their friends, teachers, inside and outside the class easily.

\section{What is vocabulary?}

Vocabulary is one of language skills and plays an important role in learning a language, because it is the basic element in the language. The small part of sentence is a word. Words are part of many vocabularies. Hilbert and Kamil (2005, p. 3) state that vocabulary is set of words for which an individual can assign meaning when listening and reading.

Based on the statement above, the writer conclude vocabulary is a total number of words with rules for combining them to make a language. Language emerges first as words, both historically, and in terms of the way, each of us learned our first and any subsequent language. The coining of new words never stops. Assumes that words are entirely important for human in order they can express their minds, make sentences, interact and also catch the meaning from content. They are not able to do nothing for interaction if they have no words or vocabulary.

In additional, the writer can assume that vocabulary is one of the important things in a language, especially learning English. Vocabulary plays an important role in language because without vocabulary nothing can be conveyed.

\section{Teaching and learning vocabulary}

Vocabulary is a basic element of language. However, Vocabulary is an important part of the English teaching process. Sometimes, the students forget the meaning of word that they have learned hence they have to practice using the words in conversation or written in a target language. So, they correctly understand about the complexity of words.

The teacher has decided to teach a related set of words by using these factors (Thornbury, 2002, pp. 75-76):

1. The level of the learners (whether beginners, intermediate, or advanced).

2. The learners 'likely familiarity with the words (learners may have met the 
words before, even though they are not part of their active vocabulary).

3. The difficulty of the items - whether, for example, they express abstract rather than concrete meanings, or whether they are difficult to pronounce.

4. Their 'teach ability' - whether, for example, they can be easily explained or demonstrated.

5. Whether items are being learned for production (in speaking and writing) or for recognition only (in listening and reading)

In general, the students have different level and ability. So an English teacher must creative in motivating the students in learning the language. Learning vocabulary is memorizing the meaning of words and to improve the pronunciation of the words well. So that, the learner can use them in the conversation. To understand the meaning of words does not mean that the learners should memorize them, but words should be memorized since they are used automatically.

Predicting what learners will need in the way of vocabulary is important in selecting what to teach; equally important is 'creating a sense of need for a word' (Allen in McCarthy 2003, p. 87) and recognizing that learner perceptions of need may conflict with the teacher' perceptions.

Therefore, there are three principle ways in which the selection of vocabulary can be influenced (McCarthy, 2003, pp. 87-88):

1. Teacher'/course book writers' predictions

2. A sense of need in the learner, fostered by the teacher

3. The learners' own sense of their needs, which may conflict with the teachers' perception

From those statements, the writer concluded that teaching vocabulary is no just memorizing words, but many ways can be used to make the teaching learning process more interesting and active.

\section{Frayer model strategy}

Frayer Model Strategy is a method that is employed to teach vocabulary that has a type of graphic organizer which allowed the students to separate the various aspects of a word or concept. Graphic organizer is one of tools to employ in teaching vocabulary. Frayer, Frederick and H.J Klausmeier in Kinberg Margot (2007, p. 26) state that the Frayer Model is especially useful for teaching vocabulary that describes complex concepts or vocabulary that describes concepts students may already know but cannot yet clearly define.

According to Karen Tankersley (2005, p. 8) Frayer Model is used to identify and define unfamiliar concepts and vocabulary. For every word, the Frayer model asks students to write down a definition and lists of characteristics, examples, and non examples". Frayer Model prompts students to understand words within the larger context of a reading selection, as it asks 
students to analyze the concept/word (definition and characteristics) and then synthesize or apply this information by thinking of examples and non examples.

Students are also required to activate prior knowledge to complete the chart that activates their prior knowledge of a topic and builds connections. The activation of prior knowledge allows new knowledge to be built upon existing schema. This model works well in learning new concept and ideas particularly because it is a type of graphic organizer which allowed the multiple pieces of information about a concept or word to be viewed in one glance. Through the employment of the Frayer Model Strategy, students learn new concept or vocabularies that give them way to greater academic achievement.

Frayer model is used to categorize students' understanding of a vocabulary word or concept they are studying. Students list the definitions, characteristics, examples, and non-examples on a chart with four quadrants. Using this model helps students develop a conceptual understanding of new vocabulary or concept. Using this particular graphic organizer helps students to think about this term in a variety of ways. It allows them to visually demonstrate what they understand and to categorize their new knowledge. This can also serve as a great tool for review or as a study aid.

By using Frayer Model Strategy in learning vocabulary continuously, the students' vocabularies will become long-term memory. With the long-term memory of words, student's vocabulary achievement will be increased. There are four-square model prompts students to think about and describe the meaning of a word or concept by:

a) Defining the term,

b) Describing its essential characteristics,

c) Providing examples of the idea, and

d) Offering non-examples of the idea.

This strategy stresses understanding words within the larger context of a reading selection by requiring students, first, to analyze the items (definition and characteristics) and, second to synthesize/apply this information by thinking of examples and non-examples.

In the theory above, the writer got the point, that Frayer Model Strategy can help students in understanding a concept or content of the lesson after they learned it. A graphic organizer is for building student vocabulary. This technique requires students to define target vocabulary and apply their knowledge by generating examples and non-examples, giving characteristics, and/or drawing a picture to illustrate the meaning of the word. This information is placed on a chart that is divided into four sections to provide a visual representation for student.

\section{Using Frayer model strategy}

The procedures of using Frayer Model Srategy by Margot Kinberg (2007, p. 26): 
1. Teacher gives hand out copies of graphic organizer of frayer model to the students.

2. The teacher explain the Frayer Model graphical organizer to the class and the teacher uses a common word to demonstrate the various components of the form. Then the teacher writes the word in the center of diagram.

3. The teacher asks students to write the word in the center of the diagram.

4. The teacher explains the information about the word to the students, and then ask students to write it in the top left block on their graphic organizer as a definition.

5. After students have a definition about the word, ask students to think about the characteristic of the word and write it in the top right block on their graphic organizer.

6. After students have definition and characteristic about the word, the teacher asks students to think about example and non-example of the word, then write it in the bottom left block for example, and in the bottom right for non-example on their graphic organizer.

\section{Methodology}

In conducting this research, the writer used experimental method. There were two classes used in this research. One class was the experimental class, in the clas, the writer taught vocabulary by using Frayer Model strategy, and one was the control class that the writer taught vocabulary by using conventional technique. This research is aim to test that there is influence in improving vocabulary mastery or not in using Frayer Model strategy.

There were two variables of this research, such as the independent variable of this research is the influence of using Frayer Model Strategy (X) and the dependent variable of this research is students' vocabulary mastery (Y).

The populations on this research is the students at the eighth class of SMP Negeri 26 Bandar Lampung in 2017/2018. The total numbers of the students are 265 students in eight classes. In this research was taken from the population, the writer took two classes available, they were class D (29 students) and class F (28 students). They are the experimental class and the control class. The writer used cluster random sampling to take the sample from the population because the classes were homogeneous.

To know the students' vocabulary mastery, the writer used vocabulary test. The writer gave the students multiple choices test which consist of 40 test items with four options A, B, C, and D. The score for every item is 2,5 for the true answer and $o$ for the false answer. Therefore, the highest score was 100 and the lowest score was 0. 


\section{Supporting technique}

In collecting the data, the writer also use some additional technique, they are:

1) Observations

Before researching the writer should have an observation, it is useful to know the condition of school, students, school environment, facilities and to get permission. Observation also useful to conduct approach system.

2) Documentation

In this research have many thing, such as: the score, the time of research, items test, so forth. Those are from document of SMPN 26 Bandar Lampung.

\section{Validity and realibility of the test}

Validity is concern chiefly with the content of the sample. An instrument is said valid if it is able to measure what it wants and can open the data of variable clearly. To do the validity test, in this research used "content validity". It means that content validity is the extent to test or measure device adequately measures the knowledge, skill or ability that it was designed to measure. That was by arranging the test items to be appropriate with the content of English curriculum at SMPN 26 Bandar Lampung.

To know the reliability of the test, the writer does some steps, they are:

1. Give the items test to the students out of the sample of research

2. Dividing the result to odd and even items

3. Analyzing the result by using product moment formula to know the coefficient correlation (Arikunto, 2010, p. 213)

4. Calculating the analysis by using spearman Brown Formula to determine the reliability of the test.

5. Consulting the result of reliability to the table of product moment.

6. Consulting the result the criteria of reliability

\section{Results}

\section{Data normality test of experimental class}

The normality test is used to know whether the sample is in normal distribution or not. Based on the students' score of experimental class, the writer got:

The highest score $=90$

The lowest score $\quad=50$

Total of the data $(n)=29$

Then, according to calculation of normality test, it was got:

$\operatorname{Span}(R) \quad=40$

Total Number of Interval Class $(K)=6$

Length of Interval Class $(P) \quad=6$

From calculation, it was obtained at significance level of 0.05 and also 
0.01 that $\chi^{2}$ ratio $<\chi^{2}$ table So the Ho hypothesis is accepted. It means that the data have normal distribution.

\section{Data normality test of control class}

The normality test is used to know whether the sample is in normal distribution or not. Based on the students' score of control class, the writer got:

The highest score $=70$

The lowest score $\quad=42$

Total of the data $(n)=28$

Then, it was got:

$\operatorname{Span}(R)$

$$
\begin{aligned}
& =28 \\
& =6 \\
& =5
\end{aligned}
$$

From calculation, it was obtained at significance level of 0,05 and also 0.01 that $\chi_{\text {ratio }}^{2}<\chi^{2}{ }_{\text {table }}$.So, the Ho hypothesis is accepted. It means that the data have normal distribution.

\section{Homogeneity test of variance}

After population had been proven that had normal distribution, the writer also conducted the examination of homogeneity variants from both samples with the following hypothesis:

From the calculation above obtained:

1. Biggest variance is the value of standard deviation from experimental $\operatorname{class}\left(\mathrm{S}_{1}{ }^{2}=97.89\right)$

2. Smallest variance is the value of standard deviation from control class $\left(\mathrm{S}_{2}{ }^{2}=50.89\right)$

In fact, at significant level 0.05 and 0.01 it was obtained $F_{\text {ratio }} \leq F_{\text {table. So, }}$ that, Ho was accepted and it means that the variance of teh data were homogeneous.

\section{The hypothesis test}

After analyzing the data, the writer got the average score of those groups. To prove the hypothesis that is how the influence of FrayerModel Strategy towards students' vocabulary mastery at eighth classes of SMPN 26 Bandar Lampung, the writer tried to see that the result of $\mathrm{t}$-test or $\mathrm{t}$-ratio. 


\section{Discussion}

Based on the research using Frayer Model Strategy at eighth class at SMPN 26 Bandar Lampung, the writer got the result that the result of the research shows that there is a significant influence of Frayer Model Strategy towards Students' Vocabulary Mastery at the eighth class of SMPN 26 Bandar Lampung in 2017/2018. It showed from the distribution list with $\mathrm{df}=55$ obtained the $t$ ratio $t_{0.95}$ or significance level of $5 \%$ and $t$ ratio to 0.99 or significance level of $1 \%$ is equal to 2.02 and 2.70. They are less than test 7.16. Finally, the writer concluded that there is a significant influence of Frayer Model Strategy towards students' vocabulary mastery at the eighth class of SMPN 26 Bandar Lampung in 2017/2018.

The writer would like to say that using Frayer Model Strategy in teaching in learning process is able to motivate students in learning English especially in learning vocabulary. By seeing the result of the analysis of the data and testing of hypothesis, the writer found the result that the null hypothesis (Ho) is rejected and alternative hypothesis. (Ha) is accepted. So that Frayer Model Strategy is a good technique that can be used to teach vocabulary and it has positive influence especially at SMPN 26 Bandar Lampung. The result of the research was appropriate with the writer excepted. So that, from the calculation above, there is a significant influence of students' vocabulary through Frayer Model Strategy.

\section{Conclusion}

The writer could give some conclusions as follows:

1. There is a significant influence of The Influence of Frayer Model Strategy towards Students' Vocabulary Mastery at Eighth Class of SMPN 26 Bandar Lampung in 2017/2018. It was proved by the result of calculation of test was higher than table. $(7.16>2.02>2.70)$.

2. The average score of students' vocabulary mastery who are taught by using Frayer Model Strategy towards Students' Vocabulary $\bar{x}_{1}=71.53$ is higher than average score of the students' vocabulary mastery who are taught by using a conventional technique $\bar{x}_{2}=56.67$ of the eighth of SMPN 26 Bandar Lampung in 2017/2018.

There are some suggestions for the students and the teachers. The students are suggested to be active and creative Not only get the knowledge from the school but also can get them from another source. And then for the teacher, they can use various techniques in teaching, especially in teaching vocabulary. In this case, the writer can use Frayer Model Strategy as one of the techniques in teaching vocabulary mastery. The teacher should be able to motivate the students to learn English especially to master the four language skills. The teacher and the students are suggested to have good cooperation and 
communication in order to be successful in teaching and learning process.

\section{References}

Arikunto. S. (2006). Prosedur penelitian: Suatu pendekatan praktik. Jakarta: Rinneka Cipta.

Cameron, Lynne. (2001). Teaching languages to young learners. Cambridge: Cambridge University Press

Harmer, Jeremy. (2001). The practice of English language teaching. England: Longman.

Harmer, Jeremy. (2004) How to teach writing. New York: Longman

Hiebert, Elfrieda H. and Kamil, Michael L. (2005). Teaching and learning vocabulary: Bringing scientific research to practice. Mahwah: New Jersey: Lawrence Erlbaum Associates.

McCarthy, Michael. (2003). Language teaching vocabulary. Oxford: Oxford University Press

Tankersley, Karen. (2005). Literacy strategies for grades 4-12: Reinforcing the threads of reading. Alexandria: Association for Supervision and Curriculum Development.

Thornbury, Scott. (2002). How to teach vocabulary. London: Pearson Education Limited.

Sudjana. (2005). Metode statistika. Bandung: Tarsito. 